\title{
Adaptation of 13 Sweet Corn Genotypes in Coastal Lands Under Drought Conditions
}

\author{
Umi Salamah ${ }^{1 *}$, Eny Rolenti Togatorop ${ }^{2}$, Dia Novita Sari ${ }^{2}$, Fahrurrozi $^{1}$, Mohammad \\ Chozin $^{1}$, Nanik Setyowati ${ }^{1}$, Zainal Muktamar ${ }^{1}$, Sigit Sudjatmiko ${ }^{1}$ \\ ${ }^{1}$ Department of Crop Production, Faculty of Agriculture, Bengkulu University, Bengkulu, Indonesia \\ ${ }^{2}$ Department of Agroekotechnology, Faculty of Agriculture, Ratu Samban University, Bengkulu, Indonesia \\ ${ }^{*}$ Corresponding author. Email: umisalamah@unib.ac.id
}

\begin{abstract}
Sweet corn is a horticultural plant that lives in the highlands. In less than optimum conditions, sensitive genotypes can thrive, especially in coastal areas with drought conditions. There were 13 genotypes of sweet maize tested in coastal areas with drought conditions. The research was conducted in Sungai Hitam, Beringin Raya, Muara Bangkahulu District, Bengkulu with an altitude of 10 masl. There were 12 genotypes from CAPS UNIB assemblies and 1 comparators were evaluated. The genotypes are G2XG8, G3XG5, G3XG6, G3XG7, G4XG5, G4XG7, G4XG8, G5XG6, G5XG7, G6XG7, G6XG8, G7XG8 and Paragon. The analysis showed that the genotypes G7xG8 and G2xG8 were the genotypes of choice in drought conditions in coastal lands during the growth phase. In the growth phase. G4XG7 is the best genotype in the variable ear weight, ear diameter, ear weight, number of ear row, number of kernels per row and yield. Most of the genotypes survived well under stress conditions. Genotypes G7xG8, G2xG8 and G4XG7 are genotypes adapted to drought conditions in coastal lands.
\end{abstract}

Keywords: coastal lands, drought condition, sweet corn

\section{INTRODUCTION}

One of the horticultural products favored by many Indonesians is sweet corn. Sweet corn is mostly consumed in a new form as a vegetable, boiled corn, and roasted corn. Sweet corn is also widely used in the food industry, corn milk, and processed products such as cakes, bread, vegetable soup, cream, milk, pizza tapping, etc [1]. Many nutritional values are contained in sweet corn, which is beneficial for the human body's metabolism. In 100 grams of sweet corn contains energy (96 cal), protein (3.5 grams), fat (1 gram), carbohydrates (22.8 grams), sugar content (16\%), calcium (3 mg), phosphorus (111 mg), iron $(0.7$ $\mathrm{mg})$, vitamin A (400 SI), vitamin B $(0.15 \mathrm{mg})$, vitamin C (12 mg) and water (72.7 gr) [2]; [3]. With the increasing use of sweet corn, the demand for sweet corn will increase. Based on data from the [4], the consumption of sweet corn per capita in new form has increased by 0.26 and $0.29 \mathrm{~kg}$ per week in 2017 and 2018. With this phenomenon, it is necessary to increase sweet corn production.

One approach that can be taken to increase the production of sweet corn further is to extend the planting field. The province of Bengkulu is an area that has a vast coastal district. There is the opportunity to expand the usage of coastal land to improve the development of sweet corn. However, the cultivation of sweet corn in coastal lands is severely constrained by water availability. Coastal land is characterized by grains of sand that are highly susceptible to wind erosion, low organic matter content, and low water retention capacity. Low plant water availability causes conditions of drought stress, causing a decrease in plant turgor, metabolic abnormalities, and a reduction in cell size and even the death of plants. Drought stress occurs when water cannot be absorbed by plants to replace losses due to transpiration, contributing to wilting. Drought stress, specifically related to water and nutrient uptake in the soil, impacts root weight and root duration [5]. Drought is correlated with conditions with low water content in the ground, according to [6], thereby reducing the capacity with plants to absorb nutrients. As a limiting factor in efforts to increase maize yield, deficiency induces low soil $\mathrm{N}$ nutritional content.

Although various approaches have been used to alleviate the problem of drought, plant breeding, either conventional breeding or genetic engineering, seems to be an efficient and economical means of tailoring crops to enable them to grow successfully in drought-prone environments [7]. Breeding for drought tolerance is further complicated since several types of abiotic stress, such as high temperatures, high irradiance, and nutrient toxicities or deficiencies can simultaneously challenge crop plants [8]. Adaptation to abiotic stresses is a quantitative trait controlled by many different genes. Enhancing crop plants' tolerance to abiotic stresses such as drought has proved to be somewhat elusive in terms of plant breeding. While many $\mathrm{C} 4$ species have significant agronomic importance, most of the research effort on improving drought tolerance has focused on maize [9].

Plant breeding programs can be used to overcome coastal land use constraints by assembling drought tolerant sweet corn varieties. CAPS (closed agriculture production 
system) is a research group with created sweet corn varieties so that 12 best genotypes were selected. A total of 12 genotypes of sweet corn were tested on various land conditions, one of which was planted in coastal land identical to dry land. The hope is that at least one droughttolerant sweet corn genotype will be selected. Droughtresistant plants are efficient in using water so that in limited soil moisture conditions, the plants are still able to grow well or produce maximum biomass for production [10].

\section{MATERIALS AND METHODS}

The study was conducted from July to September 2019 at the Experimental Garden in Beringin Raya Village, Muara Bangkahulu District, Bengkulu. The research area used is shallow swampland at an altitude of \pm 10 meters above sea level.

The materials used in this study were chicken manure, granular petroorganic fertilizer, and sweet corn seeds consisting of 13 genotypes of sweet corn assembled by CAPS University of Bengkulu, namely G2XG8, G3XG5, G3XG6, G3XG7, G4XG5, G4XG7, G4XG8, G5XG6, G5XG7, G6XG7. G6XG8, G7XG8 and Paragon, is a commercial varieties. The study used a Complete Randomized Block Design with three replication. The seeds of 13 genotypes are planted in rows. Row length is 8 $\mathrm{m}$ with a distance between rows $70 \mathrm{~cm}$ and spacing in rows $20 \mathrm{~cm}$ with a space between blocks $1 \mathrm{~m}$. A week before planting, each row is given chicken manure at a dose of 15 tons ha- ${ }^{-1}$.

Plant maintenance includes irrigation, replanting, weeding and fertilizing, planting, and controlling pest and disease. Irrigation is carried out in the afternoon for the dry soil and it did not raining. Weeding and planting are carried out simultaneously when the plants are three weeks after planting, and the second weeding is done at six months of age. Fertilization was given at three weeks after planting using organic granule petrorganic fertilizer at 20 grams/plant dose. Pest and disease control is carried out without using chemicals.

Harvesting is carried out when the plants have shown sufficient harvest criteria, namely 45-55 days after planting (dd), journalists with the appearance of dry outer hair, dark brown, hard cobs when held, and yellowish colored seeds.

The variables observed were plant height $(\mathrm{cm})$, number of leaf, stem diameter $(\mathrm{mm})$, leaf area $\left(\mathrm{cm}^{2}\right)$, ear weight $(\mathrm{cm})$, ear weight with husk $(\mathrm{g})$, ear diameter with husk $(\mathrm{mm})$, ear weight with husk $(\mathrm{g})$, ear length $(\mathrm{cm})$, ear diameter $(\mathrm{cm})$, ear weight $(\mathrm{g})$, number of seed rows, number of kernels per row, sweetness degree(brix), yield per plot (kg).

The data from were analyzed using Analysis of Variance (ANOVA) $\alpha 5 \%$. If there is a significantly efect, it will be further analyzed by DMRT (Duncan's Multiple Range Test) at the $\alpha 5 \%$ level.

\section{RESULTS AND DISCUSSION}

Plant drought tolerance may be controlled by approaches such as mass screening and reproduction, marker-assisted selection, and exogenous application to seed or developing plants of hormones and osmoprotectants, as well as dryness resistance engineering [11].

Table 1. Analysis of variance on yield and growth of sweet maize in coastal lands

\begin{tabular}{|l|r|r|r|}
\hline Variable & \multicolumn{1}{|c|}{ Bloc } & \multicolumn{1}{|c|}{ Genotype } & \multicolumn{1}{|c|}{$\begin{array}{c}\text { Coeffisien } \\
\text { Variant }\end{array}$} \\
\hline Plant height $(\mathrm{cm})$ & $50.04 \mathrm{~ns}$ & $3.14 \mathrm{~ns}$ & 9.95 \\
\hline Number of leaves & $0.31 \mathrm{~ns}$ & $0.88^{*}$ & 4.39 \\
\hline $\begin{array}{l}\text { Stem diameter } \\
(\mathrm{mm})\end{array}$ & $6.98^{*}$ & $2.71^{*}$ & 9.32 \\
\hline Leaf area $\left(\mathrm{cm}^{2}\right)$ & $122.49 \mathrm{~ns}$ & $4702.92^{*}$ & 10.73 \\
\hline Ear height $(\mathrm{cm})$ & $76.73 \mathrm{~ns}$ & $129.01^{*}$ & 14.10 \\
\hline $\begin{array}{l}\text { Ear lenght with } \\
\text { husk }(\mathrm{cm})\end{array}$ & $46.12^{* *}$ & $4.63 \mathrm{~ns}$ & 9.03 \\
\hline $\begin{array}{l}\text { Ear diameter with } \\
\text { husk (mm) }\end{array}$ & $18.98^{*}$ & $11.33 \mathrm{~ns}$ & 4.52 \\
\hline $\begin{array}{l}\text { Ear weight with } \\
\text { husk (g) }\end{array}$ & $1058.94 \mathrm{~ns}$ & $1975.09^{*}$ & 12.56 \\
\hline Ear lenght (cm) & $1.96 \mathrm{~ns}$ & $1.93 \mathrm{~ns}$ & 7.12 \\
\hline Ear diameter (mm) & $7.68 \mathrm{~ns}$ & $10.00^{*}$ & 4.45 \\
\hline Ear weight (g) & $1113.34 \mathrm{~ns}$ & $1361.53^{* *}$ & 11.57 \\
\hline Number of ear row & $1.56^{*}$ & $1.07^{*}$ & 4.83 \\
\hline $\begin{array}{l}\text { Number of kernels } \\
\text { per row }\end{array}$ & $17.61 \mathrm{~ns}$ & $16.41^{*}$ & 8.21 \\
\hline $\begin{array}{l}\text { Sweetness degree } \\
\text { (brix) }\end{array}$ & $5.87^{*}$ & $1.57 \mathrm{~ns}$ & 9.32 \\
\hline Ear weight per plot & $8,68 \mathrm{~ns}$ & $12.20^{*}$ & 32.82 \\
\hline Yield & $0.40^{*}$ & $16.71 \mathrm{~ns}$ & 20.9 \\
\hline
\end{tabular}

Note: $\mathrm{ns}=$ non significant $;{ }^{*}=$ significant; $* *=$ very significant

The results of the analysis of variance showed that the genotype factors had significant variation in the variables of leaf area, stem diameter, ear weight with weight, number of seed rows, number of seeds in rows, and ear weight per plot. The highly significant diversity factor was shown in the variable number of leaves and ear weight. As for plant height variables, ear length with weight, ear diameter, ear length, sweetness level, and yield were not significant (Table 1).

In general, coastal land has poor soil attributes, low soil moisture, high evapotranspiration, high salt content and low production of organic matter [12]. Furthermore, to improve vegetative development, sweet corn needs nitrogen [13]. Drought conditions can result in very poor capacity for Cation Exchange (CEC), C-organic and Ca, low capacity for water binding [14], loss of nitrogen Sunardi \& [15] and a reduced surface area and wide pores [16], resulting in a low capacity for water keeping.

The genotypes planted in coastal lands, based on the DMRT test, showed that the variables number of leaf, diameter of stem, and leaf area differed significantly between genotypes. For contrast, Genotype G2xG8 
displayed the better number of leaves, namely 12.27 , according to Paragon. The largest stem diameter of 17.99 was reported by Paragon as a reference, but was not substantially different from the G7xG8, G3xG5, and G2xG8 genotypes.

However, there was a substantial disparity between the genotypes in contrast to the 12 research genotypes. The leaf area between genotypes was considerably different. There would be drought problems on coastal property. The potassium $(\mathrm{K})$ factor also plays a crucial role in plant development, such as stimulating carbohydrate translocation from leaves to plant organs [17].

Drought stress decreases the size of the leaves, the length of the stem, and the proliferation of the base disturbs the connection of plant water and lowers water usage [11] More essential than the potential of plants to survive drought stress is the capacity to rebound from drought stress [18].

Similarly, between genotypes, the number of leaves and ear height varied slightly, but all of the reference genotypes appeared the same and also surpassed the comparative values. During the development process, the genotypes $\mathrm{G} 7 \mathrm{xG8}$ and $\mathrm{G} 2 \mathrm{xG8}$ are the genotypes of preference in coastal areas drought conditions (Table 2). Genotypes should be able to transmit their genes. Funded by study. CT 19, CT 17, and CT 29, the yield components of hybrid maize plants recorded the same highest yields as BISI [19].

Table 2. Average growth appearance of 13 sweet maize under drought conditions in coastal lands

\begin{tabular}{|c|c|c|c|c|c|c|c|c|}
\hline \multirow{2}{*}{$\begin{array}{l}\text { Genotipe } \\
\text { G2XG8 }\end{array}$} & \multicolumn{2}{|c|}{ Number of leaf } & \multicolumn{2}{|c|}{ Diameter of stem (mm) } & \multicolumn{2}{|c|}{ Leaf area $\left(\mathrm{cm}^{2}\right)$} & \multicolumn{2}{|c|}{ Ear height $(\mathrm{cm})$} \\
\hline & 12.27 & $\mathrm{a}$ & 15.490 & $\mathrm{ab}$ & 397.80 & abdc & 61.667 & $\mathrm{a}$ \\
\hline G3XG5 & 10.77 & $\mathrm{bc}$ & 15.530 & $\mathrm{ab}$ & 426.09 & $\mathrm{abc}$ & 54.067 & $a b$ \\
\hline G3XG6 & 9.97 & $\mathrm{dc}$ & 14.434 & $\mathrm{~b}$ & 480.90 & $\mathrm{a}$ & 42.733 & $\mathrm{~b}$ \\
\hline G3XG7 & 10.57 & bcd & 14.684 & $\mathrm{~b}$ & 388.24 & bcd & 54.467 & $\mathrm{ab}$ \\
\hline G4XG5 & 11.12 & $\mathrm{bc}$ & 14.492 & $\mathrm{~b}$ & 402.39 & abdc & 59.700 & $\mathrm{a}$ \\
\hline G4XG7 & 10.87 & $\mathrm{bc}$ & 14.401 & $\mathrm{~b}$ & 380.43 & $\mathrm{~cd}$ & 60.900 & $\mathrm{a}$ \\
\hline G4XG8 & 11.33 & $\mathrm{abc}$ & 14.980 & $\mathrm{~b}$ & 327.96 & $\mathrm{~d}$ & 51.833 & $\mathrm{ab}$ \\
\hline G5XG6 & 10.40 & $\mathrm{dc}$ & 15.244 & $\mathrm{~b}$ & 434.25 & $a b c$ & 53.667 & $\mathrm{ab}$ \\
\hline G5XG7 & 11.23 & $\mathrm{bc}$ & 14.444 & $\mathrm{~b}$ & 388.12 & bcd & 60.867 & $\mathrm{a}$ \\
\hline G6XG7 & 10.60 & bcd & 15.149 & $\mathrm{~b}$ & 420.40 & $a b c$ & 49.767 & $\mathrm{ab}$ \\
\hline G6XG8 & 11.10 & $\mathrm{Bc}$ & 14.822 & $\mathrm{~b}$ & 424.12 & $a b c$ & 49.667 & $\mathrm{ab}$ \\
\hline G7XG8 & 11.40 & $\mathrm{Ab}$ & 15.540 & $\mathrm{ab}$ & 411.91 & abdc & 61.767 & $\mathrm{a}$ \\
\hline PARAGON & 11.17 & $\mathrm{Bc}$ & 17.993 & $\mathrm{a}$ & 472.54 & $\mathrm{ab}$ & 43.913 & $\mathrm{~b}$ \\
\hline
\end{tabular}

Noted: A number followed by the same letter in the same variable shows that there is no significant difference based on the DMRT test $\alpha=5 \%$

Tabel 3. Average yield performance and yield components of 13 sweet maize with drought conditions in coastal lands

\begin{tabular}{|c|c|c|c|c|c|c|c|c|c|c|c|c|}
\hline \multirow{2}{*}{$\begin{array}{l}\text { Genoype } \\
\text { G2XG8 }\end{array}$} & \multicolumn{2}{|c|}{$\begin{array}{c}\text { Ear weight } \\
\text { with husk (g) }\end{array}$} & \multicolumn{2}{|c|}{$\begin{array}{l}\text { Ear diameter } \\
(\mathrm{mm})\end{array}$} & \multicolumn{2}{|c|}{ Ear weight (g) } & \multicolumn{2}{|c|}{$\begin{array}{c}\text { Number of ear } \\
\text { row }\end{array}$} & \multicolumn{2}{|c|}{$\begin{array}{l}\text { Number of } \\
\text { kernels per } \\
\text { row }\end{array}$} & \multicolumn{2}{|c|}{$\begin{array}{l}\text { Yield per plot } \\
(\mathrm{kg})\end{array}$} \\
\hline & 236.77 & $\mathrm{abc}$ & 48.390 & $a b c$ & 173.50 & bcd & 140.333 & $\mathrm{ab}$ & 32.800 & $a b c$ & 6.033 & $\mathrm{bc}$ \\
\hline G3XG5 & 271.57 & $a b c$ & 49.320 & $a b$ & 205.27 & $a b$ & 148.000 & $\mathrm{a}$ & 30.967 & $\mathrm{bc}$ & 7.700 & $a b c$ \\
\hline G3XG6 & 227.70 & $\mathrm{bc}$ & 45.771 & bcd & 164.07 & $\mathrm{~cd}$ & 127.000 & $\mathrm{c}$ & 29.133 & $\mathrm{c}$ & 4.033 & $\mathrm{c}$ \\
\hline G3XG7 & 231.23 & $\mathrm{bc}$ & 45.112 & $\mathrm{~cd}$ & 164.10 & $\mathrm{~cd}$ & 134.667 & $\mathrm{bc}$ & 28.867 & $\mathrm{c}$ & 5.567 & $\mathrm{c}$ \\
\hline G4XG5 & 232.07 & $\mathrm{bc}$ & 45.779 & bcd & 171.60 & bcd & 138.667 & $a b c$ & 36.367 & $\mathrm{a}$ & 4.167 & $\mathrm{c}$ \\
\hline G4XG7 & 253.80 & $a b c$ & 46.737 & abcd & 194.93 & $a b c$ & 129.333 & $\mathrm{bc}$ & 35.100 & $\mathrm{ab}$ & 9.500 & $a b$ \\
\hline G4XG8 & 192.13 & $\mathrm{c}$ & 43.975 & $\mathrm{~d}$ & 147.47 & d & 126.667 & $\mathrm{c}$ & 31.333 & $\mathrm{bc}$ & 4.333 & c \\
\hline G5XG6 & 263.60 & $\mathrm{abc}$ & 46.243 & abcd & 182.87 & bcd & 138.667 & $a b c$ & 32.733 & $a b c$ & 6.933 & $a b c$ \\
\hline G5XG7 & 236.60 & $a b c$ & 45.199 & $\mathrm{~cd}$ & 173.93 & bcd & 134.667 & $\mathrm{bc}$ & 33.233 & $a b c$ & 7.067 & $a b c$ \\
\hline G6XG7 & 236.33 & $\mathrm{abc}$ & 45.488 & bcd & 167.73 & bcd & 130.407 & $\mathrm{bc}$ & 29.933 & $\mathrm{c}$ & 6.800 & $a b c$ \\
\hline G6XG8 & 224.00 & $\mathrm{bc}$ & 44.229 & d & 156.77 & $\mathrm{~cd}$ & 135.000 & $\mathrm{bc}$ & 30.867 & $\mathrm{bc}$ & 5.467 & $\mathrm{c}$ \\
\hline G7XG8 & 219.67 & $\mathrm{bc}$ & 46.063 & abcd & 154.00 & d & 130.852 & $\mathrm{bc}$ & 29.648 & $\mathrm{c}$ & 3.733 & $\mathrm{c}$ \\
\hline PARAGON & 293.57 & $\mathrm{a}$ & 49.871 & $\mathrm{a}$ & 222.27 & $\mathrm{a}$ & 137.000 & $a b c$ & 29.567 & $\mathrm{c}$ & 10.033 & $\mathrm{a}$ \\
\hline
\end{tabular}

Noted: A number followed by the same letter in the same variable shows that there is no significant difference based on the DMRT test $\alpha=5 \%$ 
The genotypes showed various characters examined on coastal lands with drought conditions. The measured genotypes in the yield portion appeared the same relative to the control varieties. G4XG7 is the best genotype for ear weight, ear diameter, ear weight, number of ear rows, number of kernel per row, and yield among the 12 genotypes examined. This genotype adapted to drought conditions in coastal lands. Large ear diameter, the weight of the cob becomes heavy. Sweet corn is a plant that can growth under stress conditions. So that the conditions are not optimal, some genotypes have a good response (Table $3)$.

Some hybrid maize in the Sudan savannah zone of West and Central Africa is tolerance to water stress recorded higher grain yield [20]. Genetic improvement of crops for drought tolerance requires investigation of the possible components of drought tolerance and exploration of drought tolerance and exploration of the genetic variation of the crops [21].

\section{CONCLUSION}

Genotypes G7xG8, G2xG8 and G4XG7 are genotypes adapted to drought conditions in coastal lands.

\section{REFERENCES}

[1] M. Syukur, A. Rifianto, 'Jagung manis', Penebar Swadaya Grup. 2013.

[2] Wahyudi and Marman, 'Proses Pembuatan dan Analisis Mutu Yoghurt, Jurnal Buletin Teknik Pertanian, vol. 11, no.1, 2006.

[3] Suarni, and M. Yasin, 'Jagung sebagai sumber pangan fungsional, Iptek Tanaman Pangan, vol. 6, no. 1, pp. 41-56, 2011.

[4] Badan Pusat Statistik, 'Rata-rata konsumsi per kapita seminggu beberapa macam bahan makanan penting, 2017-2018', 2019.

[5] A. Shahriar, A.B. Puteh, G.B. Saleh, and A.B.A. Rahim, 'Selecting drought resistant sweet corn cultivars based on germination percentage and seedling proline content under osmotic potentials stress', Researchon on Crop Ecophysiology, vol. 9, no. 1, pp. 45-54, 2014.

[6] M.R. Aulya, S.T. Subaedah, and A. Takdir, 'Karakterisasi genotipe jagung toleran kekeringan di lahan kering', Jurnal Ilmu Pertanian, vol. 4, no. 1, pp. 2541-7460, 2019.

[7] M. Ashraf, 'Inducing drought tolerance in plants: recent advances', Biotechnology advances, vol. 28, no. 1, pp. 169-183, 2010.

[8] D. Fleury, S. Jefferies, H. Kuchel, and P. Langridge, 'Genetic and genomic tools to improve drought tolerance in wheat', Journal of Experimental Botany, vol. 61, no. 12, pp. 3211-3222, 2010.

[9] M.S. Lopes, J.L. Araus, P.D. Van Heerden, and C.H. Foyer, 'Enhancing drought tolerance in C4 crops', Journal of experimental botany, vol. 62, no. 9, pp. 3135-3153, 2011.
[10] J.B. Passioura and J.F. Angus, 'Improving productivity of crops in water-limited environments. In Advances in Agronomy, (Donald L. Sparks, ed.)', no. 106, pp. 37-75, Academic Press, Burlington, 2010.

[11] M. Farooq, A. Wahid, N. Kobayashi, D. B. S. M. A Fujita, and S.M.A Basra, 'Plant drought stress: effects, mechanisms and management, In Sustainable agriculture', Springer, Dordrecht, pp. 153-188, 2009.

[12] Z. Shi, Y, R.C. Li, and F. Wang, 'Makeschine, Assessment of temporal and spatial variability of soil salinity in a coastal salinefield', Environmental Geology, vol. 48, no. 2, pp. 171-178, 2005.

[13] P. Lingga, 'Petunjuk Penggunaan Pupuk. Penebar Swadaya', Jakarta, 2003.

[14] R. Rajiman, P. Yudono, E. Sulistyaningsih, and E. Hanudin, 'Pengaruh pembenah tanah terhadap sifat fisika tanah dan hasil bawang merah pada lahan pasir pantai bugel Kabupaten Kulon Progo', Agrin, vol. 12, no. 1, pp. 67-77, 2008, doi: http://dx.doi.org/10.20884/1. agrin.2008.1 2.1.80.

[15] Sunardi, and Y. Sarjono, 'Penentuan Kandungan Unsur Makro pada Lahan Pasir Pantai Samas Bantul dengan Metode Analisis Aktivasi Neutron (AAN), Prosiding PPI-PDIPTN, 10 Juli 2007, Yogyakarta', Pusat Teknologi Akselerator dan Proses Bahan, Badan Tenaga Nuklir Nasional (BATAN), 2007.

[16] S.R.P. Sitorus, E. Kusumastuti, and L.N. Badri, 'Karakteristik dan teknik rehabilitasi lahan pasca penambangan timah di Pulau Bangka dan Singkep', Jurnal Tanah dan Iklim, vol. 27, pp. 57-73, 2008.

[17] L. Aguslina, 'Dasar Nutrisi Tanaman', PT. Rineka Cipta, Jakarta, 2004.

[18] J.A. Malabuyoc, E.L. Aragon, and S.K. De Datta, Recovery From Drought-Induced Desiccation At The Vegetative Growth Stage In Direct-Seeded Rainfed Rice', Field Crops Research, vol. 10, pp. 105$112,1985$.

[19] W.D.R. Gea, R. Rustikawati, and E. Turmudi, 'Keragaan pertumbuhan dan komponen hasil 15 genotipe jagung hibrida di lahan pesisir kota Bengkulu', Doctoral dissertation, Universitas Bengkulu, 2019.

[20] A.Y. Kamara, A. Menkir, B. Badu-Apraku, and O. Ibikunle, 'The influence of drought stress on growth, yield and yield components of selected maize genotypes', The journal of agricultural science, vol. 141 , no. $1,2003$.

[21] S.S. Dhanda, G.S, Sethi, and R.K. Behl, Indices of drought tolerance in wheat genotypes at early stages of plant growth. Journal of agronomy and crop science, vol. 190, no. 1, pp. 6-12, 2004. 